\section{TEXT V KOMUNIKÁCII}

Text a divadlo. (Eds. Aleš Merenus - Iva Mikulová - Jitka Šotkovská). Praha : Academia, 2020. 412 s. ISBN 978-80-200-3108-2.

V slovenskom teatrologickom a literárnovednom kontexte iba zriedkakedy vzniká výskum alebo texty monografického či zborníkového charakteru, ktoré by sa venovali teórii divadla. V tejto chvíli poslednou prácou od slovenského autora/ky je učebný text Evy Kušnírovej Úvod do divadelného umenia (Prešovská univerzita, 2021). Z publikácií ostatných desiatich rokov sem patria napríklad monografie z vydavatel'skej činnosti Univerzity Konštantína Filozofa v Nitre Scénický dizajn Petra Janků (2012), Lope de Vega. Nové umenie ako písat' komédie v dnešných časoch Petry Pappovej (2013) či Translácia v divadelnej komunikácii autoriek Edity Gromovej, Sone Hodákovej, Emílie Janecovej (vyd. Perez), Daniely Müglovej a Antónie Filípkovej (2013). Z edičnej činnosti Divadelného ústavu a Vysokej školy múzických umení v Bratislave sem môžeme zaradit’ monografické texty Milana Čorbu Kostýmová tvorba (Divadelný ústav, 2009) a Kultúra a civilizácia (Divadelný ústav, 2014) či Peripetie moderny Boženy Čahojovej (VŠMU, 2016). Posledné dve zo zmienených monografií, spolu $\mathrm{s}$ témami niektorých zborníkov (a príspevkami $\mathrm{v}$ nich) $\mathrm{z}$ pravidelných každoročných medzinárodných teatrologických konferencií Fakulty dramatických umení Akadémie umení v Banskej Bystrici, sú však skôr esejisticko-filozofickými textami než teatrologickými prácami zásadného významu.

Väčšina publikácií z oblasti teórie divadla je prekladového charakteru, no často významným spôsobom rozširuje myslenie o divadle aj $\mathrm{v}$ slovenskom humanitnom a spoločenskom kontexte. Či už ide - aj zo starších vydaní - o Divadelný slovník Patrica Pavisa (Divadelný ústav, 2004), Postdramatické divadlo Hansa-Thiesa Lehmanna (Divadelný ústav, 2007), Smrt' tragédie Georgea Steinera (Divadelný ústav, 2011), Úvod do divadelnej vedy Christophera Balmeho (Divadelný ústav, 2018) a mnohé d’alšie. Slovenská divadelná veda sa však primárne orientuje na dejiny slovenského divadla, či už všeobecné alebo týkajúce sa osobností, života divadiel, prípadne festivalov. Uvedené platí nielen pre profe- sionálnu scénu, ale aj amatérsku divadelnú kultúru.

Vel'mi odlišná situácia je v českej divadelnej vede. Popri prekladových dielach z oblasti teórie divadla sú často vydávané aj práce českých teatrológov, literárnych vedcov či odborníkov z iných humanitných vied, osobitne sa kladie dôraz na publikovanie vynikajúcich dizertačných prác. Medzi posledné teoretické diela patrí zborník štúdií Text a divadlo (2020) trojice editorov, Aleša Merenusa, Ivy Mikulovej a Jitky Šotkovskej. Práca vznikla na základe rovnomenného kolokvia, ktoré sa uskutočnilo 7. a 8. júna 2018 v Prahe pod vedením Tímu pre výskum moderného českého divadla pri Ústave pre českú literatúru Akadémie vied Českej republiky (AV ČR). Zúčastnil sa ho celý rad nielen českých, ale aj slovenských teatrológov a literárnych vedcov. Zaujímavost’ou je skutočnost', že publikácia vznikla s podporou Akademickej prémie Praemium Academiae, ktorú AV ĆR využíva ako nástroj, ktorý má vynikajúcim vedeckým osobnostiam poskytnút dostatok finančných prostriedkov a morálnu podporu na rozvinutie ich potenciálu v prospech nielen AV ČR, ale celej českej vedy. Takouto osobnostou je aj prof. PhDr. Pavel Janoušek, DSc. (1956), popredný odborník na literárnu a divadelnú teóriu a dejiny českej literatúry 20. storočia. V roku, ked prémiu získal, bol v histórii jej udel'ovania iba druhým laureátom z oblasti humanitných vied. Zborník tak vznikol ako pocta dlhoročnému a koncepčnému výskumu profesora Janouška v uvedených vedných oblastiach - a to je aj dôvod, prečo úvod patrí jeho vel'mi obsiahlej štúdii s názvom Divadlo a text jako průnik fuzzy množin/Úvaha nejen teoretická.

Zborník je rozčlenený do šiestich kapitol, v ktorých sa z rôznych uhlov pohladu skúma vztah medzi textom a divadlom. Jadrom výskumu je otázka, ako je možné v súčasnosti chápat' zhody a rozdiely medzi divadelnou a literárnou komunikáciou $\mathrm{v}$ historických a aktuálnych súvislostiach. Jednotliví prispievatelia nachádzali odpovede tak $\mathrm{v}$ myslení starých, ako aj nových teórií o dramatickom texte a divadle.

Základný metodologický prístup $\mathrm{k}$ téme možno u Pavla Janouška charakterizovat ako kombináciu úvah, analýz aktuálnej situácie v myslení o dráme či dramatickom texte s historickými pragmatickými a teoretickými 
komparáciami. Prostredníctvom tohto prístupu dôsledne sleduje zmeny v chápaní vztahu textu a divadla od minulosti až po súčasnosṫ. Neprestáva mat' pritom na zreteli referenčnú funkciu drámy, stratu jej dominancie sleduje až $\mathrm{k}$ Osolsoběho ostenzii a $\mathrm{k}$ súčasným populárnym teóriám o performancii a performativite. Poslednými odkazuje nielen na problematiku nad- či podinterpretácie dramatického textu, pri ktorej zmenu statusu dramatického textu ovplyvňuje práve zmena paradigmy, ale aj na otázku (všeobecne naformulované) prekladu dramatického textu do inej sociálnej či spoločenskej situácie. V jeho koncepcii chápania dramatiky je zásadným pojmom divadelný projekt, ktorý chápe ako medzistupeň medzi sémanticky a semioticky uzavretou dramatikou a jej otvoreným, aj ked' už typicky divadelne fixovaným - fikčným inscenačným tvarom. Zvolený typ teoretickej či pragmatickej argumentácie akýkol'vek názor vyjasňuje.

Prvú kapitolu s názvom Teorie současného dramatu/divadelního textu otvára text $K$ současnému českému veršovanému dramatu, v ktorom Robert Kolár ponúka dôslednú analýzu vyše dvadsiatich pôvodných českých hier, ktoré vznikli na prelome osemdesiatych a devätdesiatych rokov 20. storočia, a to z hladiska využívania viazaného a volného verša. Dospieva k zisteniu, že viazaný verš je spätý s groteskou, absurditou, paródiou a travestiou, zatial' čo vol'ný verš sa najčastejšie vyskytuje v lyrických dramatických textoch. Štúdia Lenky Jungmanovej s provokatívnym názvom Zi̊stane divadelní hra dramatem? Poznámky $k$ teoretickému vymezení dramatu sa zaoberá podstatou chápania drámy ako hybridného (dvojakého) textu vzhladom na to, že funguje „(...) ve dvou médiích: Drama je dílem literárním, protokolem fikčného světa díla, které můžeme recipovat čtením, a zároveň protokolem inscenace, tedy díla divadelního, který recipujeme přímou účastí." (s. 132) Osciláciu konvenčného chápania drámy medzi jedným (literárnym) či druhým (performatívnym) smerom sleduje na teoretických príkladoch z tvorby bardov českej a svetovej teatrológie, literárnej vedy a lingvistiky (Otakar Zich, Jiří Veltruský, Aristeles, Roman Ingarden, Ivo Osolsobě, Gerda Peschman). Na typické miesta prechodu z jednej roviny čítania dramatiky do druhej poukazuje prostredníctvom hier experimentálnej dramatiky, pričom v jadre jej pozornosti je hra Bambiland Elfriede Jelinek.

Zuzana Augustová sa v príspevku s názvom Teatralita textu venuje problematike poetickej funkcie reči, tak ako ju chápe vyššie spomínaná nemecká anglistka a teatrologička Gerda Poschmann v monografii Der nicht mehr dramatische Theater-tex (Už nikdy dramatický divadelný text, 1997). Spája s ňou kategóriu intertextuality, vd’aka ktorej je autoreferenčnost’ textu otvorená neobmedzenému množstvu významov. Na príklade už zmieneného Bambilandu ukazuje podoby implicitnej a explicitnej intertextuality. Aj Tereza Pavelková sa príspevku s názvom "Nedramatický" text $v$ kontextu současného psaní pro divadlo: Kategorie časoprostoru $v$ textu on není jako on dominantne venuje práci Poschmanovej, no na rozdiel od predchádzajúcich príspevkov sa zaoberá jej tvrdením o zániku dominancie textovej predlohy - drámy (v zmysle dramatiky s konvenčnou štruktúrou) a jej chápaním dramatiky ako divadelného dramatického textu, pre ktorý je príznačná poetická funkcia a sebareflexívnost'.

Kapitola s názvom Poetiky dramatické a režijné sa začína príspevkom Aleša Merenusa Historická poetika českého dramatu jako prostředek pro výzkum naratívní kultury (?). Autor obracia pozornost' na problematiku historickej poetiky (Vladimír Macura, Bořivoj Srba, Pavel Janoušek a i.), ktorá v prepojení na teóriu fikčných svetov (naratológia) umožňuje divadelnej vede otvorit’ sa metódam iných vedných odborov o umení ako takom. Aj ked' si uvedomuje úskalia svojho prístupu, prepojenie dramatiky s kultúrnou naratológiou a historickou poetikou by podla jeho názoru umožnilo pozriet sa na dramatiku aj ako na súčast’ českej kultúry rozprávania. V nasledujúcom príspevku s názvom Poválečný režisérizmus aneb špatný poměr k autorovi sa Iva Mikulová venuje genéze chápania pojmu režisérizmus a jeho dvom hlavným podobám: textovej/literárnej a divadelnej. Pod prvým rozumie napríklad násilné aktualizácie textu, pod druhým svojvolnost̉ režiséra pri hl'adaní výsledného tvaru inscenácie.

Tretiu kapitolu s názvom Dobové fenomény - publikování a recepce díla uvádza príspevok Dima Mitrevského Metodologické zkoumání divadelního překladu na př́kladu Žebrácké opery (Gay-Brecht-Havel). Jadrom jeho záuj$\mathrm{mu} \mathrm{v}$ rámci translatológie je porovnávanie 
možností, ktoré poskytuje textocentristický a scénocentrický preklad, pričom sa venuje aj tradičným divadelno-translačným formám (prepis, verzia, dramatizácia atd'.). Jana Bžochová Wild sa v príspevku s názvom "Dva domy, rovnako vážené"? Shakespeare v českých komentároch slovenských knižných vydaní dominantne zaoberá kritickým rozborom paratextov vo vydaniach prekladov Shakespearových hier od Aloisa Bejblíka, vrátane nedôsledností či zásadných nedostatkov $\mathrm{v}$ prekladatel'ských poznámkach a komentároch. Súčastou štúdie je aj stručný pohl'ad do dejín prekladu hier Shakespeara na Slovensku a v Českej republike. Príspevok Davida Kroča Knižní publikování dramatického textu jako znak literárnosti sa koncentruje na jednu zo základných otázok teórie drámy, ktorá sa týka zmyslu interpretácie a analýzy vydaných dramatických textov, pretože sú predurčené pre inscenovanie, a nie na čítanie. Opiera sa aj o výskum Pavla Janouška, ktorý za hlavný znak tohto typu dramatických textov považuje ich literárnost'. Venuje sa i problematike textov, ktoré nikdy neboli publikované.

Úvodný príspevok štvrtej kapitoly s názvom Intertextové vztahy - v operním libretu a dramatizacích literárních textů patrí Michaele Mojžišovej a štúdii Metamorfózy operného libreta (s prihliadnutím na slovenskú opernú tvorbu). Na pozadí analýzy významných svetových operných diel (Philip Glass - Robert Wilson: Eistein on the Beach, 1975 - 1976 a i.) a až ikonických diel slovenskej opernej tvorby, vrátane alternatívnej scény (Juraj Beneš: The Players, 1994; L'ubo Burgr: Smrt' v kuchyni, 2002; Marek Piaček: Lest' rozmyslu, 2012 a i.) sa popri inom zaoberá problematikou poetiky nefixovaných operných textov. Katarína Cupanová v príspevku Možnosti dramatizácie a aktualizácie nedramatického textu (na príklade diel klasikov slovenskej literatúry) v úvode nepresne konštatuje, že $\mathrm{v}$ slovenskom teatrologickom kontexte nie je spracovaná téma dramatizácie literárnej predlohy (napr. Ol'ga Panovová: Cesty detskej literatúry na javisko, 1989; čiastočne Július Pašteka: Estetické paralely umenia, 1976 a Dagmar Inštitorisová: O výrazovej variabilite divadelného diela, 2001; Tibor Žilka: Vademecum poetiky, 2006 a i.), jej vlastný text je pragmaticko-recenzentskou analýzou dvoch slovenských inscenácií.
Kapitola s názvom Dramatičtí autoři obsahuje príspevky $O$ tzv. nesmrtelnosti díla dramatického aneb co zbylo z Hilberta od Michala Fráneka, Inovácie a limity v dramatickej tvorbe Júliusa Barča-Ivana od Dagmar Kročanovej a Druhý život české modelové dramatiky (na př́kladu soudobých inscenací her Václava Havla) od Jitky Šotkovskej, ktoré sú viac-menej peotologickým rozborom dramatickej tvorby zvolených osobností českej a slovenskej dramatiky. V prvom príspevku ide o zakladatel’a českej modernej dramatiky, v druhom o osobnost' spätú so snahou o modernitu slovenskej dramatickej tvorby a posledná primárne reprezentuje výrazovú kategóriu antiiluzívnosti.

Posledná kapitola s názvom Performeři a písničkáři pozostáva opät z troch príspevkov: Vladimír Vysockij - (ne)prítomný autor v dramatickom texte a jeho inscenácii od Zuzany Spodniakovej, Dmitrij Prigov: Suspendácia a performativita textu od Jakuba Kapičiaka a Text versus obraz od Dáše Čiripovej. Spodniakovej príspevok akcentuje nielen zástoj Vysockého v rámci ruskej i svetovej dobovej kultúry, ale podnetné sú aj paralely s ruským skoromochom (typ Pantaloneho), dokumentárnym divadlom atd'. Autorka neobišla ani spoločensko-politický dopad Vysockého tvorby na mnohé generácie umelcov. Jakub Kapičiak sa sústreduje na problematiku identity a performativity textu, ktorú vysvetluje na diele Dmitrija Prigova, predstavitel'a ruského konceptualizmu. V kontexte príspevkov v zborníku je inšpirujúcim jeho chápanie pojmu antitextovosti, pretože v kontexte tvorby zvolenej osobnosti ho chápe ako manifestáciu autorovho "ja“, teda autorskej perfomativity. A napokon príspevok Dáše Čiripovej sa pokúša formulovat spojivá medzitextom a obrazom hlavne na príklade tvorby bratislavského divadla Debris company a na pozadí niektorých teórii obrazu.

Zborníku sa nedá upriet vysoká miera relevantnosti. Predstavuje velmi funkčný model súčasného teoretického a kritického myslenia o dramatike v kontexte aktuálnych i historických divadelno-inscenačných súvislostí. Zároveň je návodom na to, ako pokračovat v rozpravách o dôležitých otázkach divadelného umenia $\mathrm{v}$ teoretickom i pragmatickom rozmere.

\section{Dagmar Inštitorisová}

